\title{
The roots of the city. Creative food systems in European small towns
}

\author{
Maria Mar Delgado-Serrano \\ Universidad de Córdoba - Córdoba - España \\ ORCID: http://orcid.org/0000-0003-0171-6097 \\ Antonio Zafra \\ Asociación para el Desarrollo del Guadajoz - Baena - España
}

Miguel Sousa

Inova-Porto - Portugal

\begin{abstract}
This communication presents the results of AGRI-URBAN, an EU-funded project, where a group of eleven European small and medium sized cities with a relative specialization in agrifood production have explored ways to rethink their food systems. The project was led by policymakers in each city and has engaged stakeholders and most importantly local citizens in every stage of the planning and implementation of initiatives. The main objectives have been to develop an inclusive, coherent and reflexive urban-rural food governance system through municipal integrated action plans; to deploy a more solid social and physical infrastructure to reduce the distance between producers and consumers and to promote circular economy; to create reliable markets for quality food producers, resulting in new opportunities for SMEs development; to experiment new forms of entrepreneurship in the agricultural sector, and to create new jobs and skills linked to the agri-food system. The project added value has been to facilitate city-to-city learning with 'transnational' visits that enabled participants to engage in peer discussions and develop a deeper understanding of shared issues as well as to utilize opportunities for examining relevant local good practices in host cities and create networking opportunities. The communication displays the different local level and bottom-up initiatives these cities have activated by means of innovation and new business models and strategies, organized around four cross-cutting topics: Ensuring short circuits; Smart land use; Business development of SMEs and Local public procurement, and how these initiatives have been articulated in sustainable urban food agendas.
\end{abstract}

Keywords: Food systems. Territorial development. Rural small towns.

\section{Las raíces de la ciudad. Sistemas alimentarios creativos en ciudades europeas de tamaño intermedio o pequeño}

\section{Resumen}

Este trabajo presenta los resultados de AGRI-URBAN, un proyecto financiado por la Unión Europea, en el que un grupo de once pequeñas y medianas ciudades, especializadas en producción agroalimentaria, han explorado como repensar sus sistemas agroalimentarios. 
Los políticos y decisores en cada ciudad han liderado el proyecto, y los actores clave y los ciudadanos han sido incluido en cada una de las fases de planificación y ejecución de iniciativas. Los principales objetivos han sido: desarrollar un sistema de gobernanza alimentaria inclusivo, coherente y sólido, además de articulado en torno a las relaciones ruralurbano, a través de la elaboración de planes de acción integrados; desarrollar infraestructuras físicas y sociales que permitan acortar la distancia entre productores y consumidores de productos alimentarios para promover la economía circular; crear mercados seguros para los productores de alimentos de calidad y así crear oportunidades para el desarrollo de pequeñas y medianas empresas; experimentar nuevas formas de emprendimiento en el sector agrícola y crear nuevos empleos y competencias ligados al sector agroalimentario. El valor añadido del proyecto ha permitido facilitar el aprendizaje entre ciudades, gracias a las visitas transnacionales para intercambiar conocimientos, analizar las problemáticas comunes, aprender de las buenas prácticas existentes en las ciudades participantes y finalmente, crear redes. Este trabajo presenta las diferentes iniciativas locales que estas ciudades han puesto en marcha gracias a la innovación y la creación de nuevos modelos de negocio y de estrategias, organizadas en torno a 4 temas principales: circuitos cortos agroalimentarios, uso sostenible del suelo, desarrollo de pequeñas y medianas empresas y compra pública local, así como la articulación de todas estas iniciativas en agendas agroalimentarias sostenibles.

Palabras clave: Sistemas alimentarios. Desarrollo territorial. Pequeñas ciudades rurales.

\section{As raízes da cidade. Sistemas alimentares criativos nas pequenas cidades europeias}

\section{Resumo}

Esta comunicação apresenta os resultados do projeto AGRI-URBAN financiado pela UE, onde um grupo de onze cidades europeias de pequena e média dimensão, com uma especialização relativa na produção agroalimentar, explorou formas de repensar os seus sistemas alimentares. O projeto teve um liderança politica alicerçada num conjunto de atores locais interessados no sector agroalimentar que participaram nas diferentes fases do projeto, nomeadamente: planeamento e implementação. Os principais objetivos do projeto foi desenvolver um sistema inclusivo, coerente e reflexivo de governança alimentar ruralurbana, através de: planos de ação integrados; criar uma infra-estrutura social e física mais sólida para reduzir a distância entre produtores e consumidores, promovendo assim uma economia circular; criar mercados fiáveis para produtores de alimentos de qualidade, resultando em novas oportunidades para o desenvolvimento das PME; experimentar novas formas de empreendedorismo no sector agrícola e criar novos postos de trabalho e competências ligados ao sistema agroalimentar. Uma das mais valias do projeto foi facilitar a troca de conhecimento e aprendizagem entre cidades através de uma série de visitas "transnacionais" que permitiram aos parceiros do projeto participar em grupos de discussões e desenvolver um entendimento mais aprofundado do tema, bem como experienciar exemplos concretos que estão em pratica nas diferentes cidades e criar oportunidades de networking. A comunicação evidencia as diferentes iniciativas de nível local e de "bottomup" que as cidades ativaram por meio de processos inovadores, novos modelos e estratégias de negócios, organizados em torno de quatro tópicos transversais: Garantindo curtoscircuitos; Uso inteligente da terra; Desenvolvimento de negócios de PMEs e compras públicas locais, e como estas iniciativas foram articuladas em agendas alimentares urbanas sustentáveis.

Palavras-chave: Sistemas alimentares. Desenvolvimento territorial. Pequenas cidades rurais. 


\section{Introduction}

Food is actually one of the main urban challenges, but food is also at the centre of the debate on sustainable development (UNEP, 2016). Food systems are essential for sustainable development: they are at the nexus that links food security, nutrition and human health, the viability of ecosystems, climate change, and social justice (Caron et al., 2018).

More than 7500 million people need to be fed healthily, equitably and affordably while maintaining the ecosystems on which life depends. The evidence of the impact of diet on the health of people and the planet has grown enormously during recent decades, yet changing consumer eating habits, even for public health alone, not to mention planetary health, is proving difficult.

Agri-food production is a mature industry that continues to play an important role in terms of GDP, employment and environmental sustainability. Power in the food system is becoming increasingly concentrated with mega-mergers in the seed, agri-chemical, fertilizer, animal genetics and farm machinery industries; this reinforces the industrial farming model, exacerbating its social and environmental costs. Globally, farmers are increasingly reliant on a handful and suppliers and buyers, squeezing their incomes. There is an urgent need to connect research and policy around an innovative and more integrated sustainable food security agenda.

That is why new growth potentials must be activated by means of innovation, new business models and strategies. Small and medium size European cities, especially those located in rural areas and with a local economy linked to agriculture and the agri-food system can play a leading role to face this urban challenge.

This communication presents the results of AGRI-URBAN, one of the 21 URBACT III Action Planning Networks that has explored the role of 'rural towns' in addressing agri-food production. URBACT is the European Territorial Cooperation programme that aims to foster sustainable integrated urban development in cities across Europe. URBACT's mission is to enable cities to work together and develop integrated solutions to common urban challenges, by networking, learning from one another's experiences, drawing lessons and identifying good practices to improve urban policies. The project has been developed by 11 European cities working towards sustainable food systems, with the aim to stimulate resilience, employment and job creation.

AGRI-URBAN rationale has been about rethinking food systems in small and medium-sized cities that have a relative specialization in Agri-food production. The network vision has been to place small and medium-sized European cities at the core of a growing global movement that recognizes that the current complexity of food systems based on economies of scale is causing economical, societal and environmental challenges to cities and rural areas. Closer links between mediumsized rural cities and nearby cities are not only societally and environmentally beneficial, but also ensure regional economic development.

Network members ranged from some of Europe's leading exponents in this area - such as Mouans-Sartoux, a long-standing pioneer and Sodertalje with its innovations in public procurement - to others addressing a systemic food policy for the first time. All these cities have worked together for nearly three years, sharing knowledge, learning from each other and creating a durable and important legacy. 


\section{AGRI-URBAN cities}

AGRI-URBAN covered a wide geographical distribution across Europe. The eleven partner cities have worked through a double path. On the one hand, each city had proposed a specific Integrated Action Plan (IAP) to be implemented in a short time period. On the other, the network and the expert team supporting the cities during the development of the project have focused their activities on a theme with the hope to identify good practices and stimulate good solutions to face actual challenges.

The cities involved are presented in Figure 1. Table 1 describes the cities and their visions.

Figure 1 - AGRI-URBAN cities map

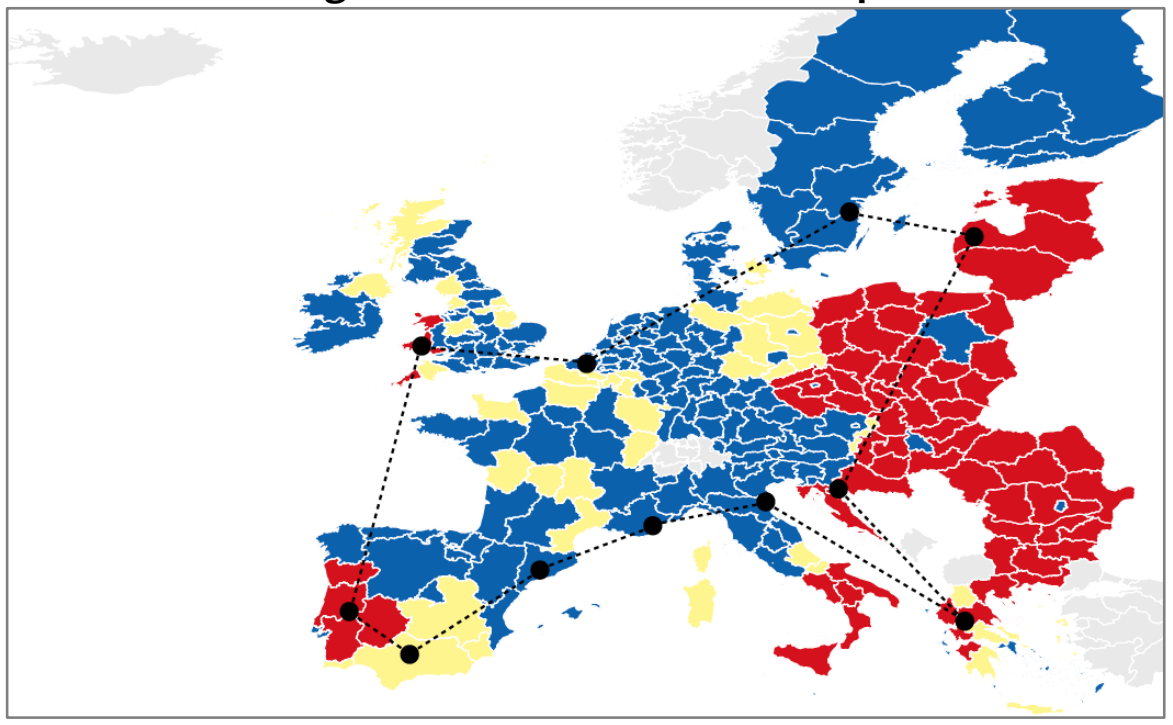

Source: authors. 
Table 1 - AGRI-URBAN cities and its vision

\begin{tabular}{|c|c|c|}
\hline City & Country & Vision \\
\hline Baena & Spain & To be the "European Capital of Olive Oil" \\
\hline Jelgava LM & Latvia & $\begin{array}{l}\text { A sustainable territory in the central part of the } \\
\text { Baltic states for the implementation of business } \\
\text { activity ideas that contribute to the growth and } \\
\text { the improved quality of life of our citizens }\end{array}$ \\
\hline Fundão & Portugal & $\begin{array}{l}\text { To promote healthier food based on our local } \\
\text { products at our school canteens }\end{array}$ \\
\hline Petrinja & Croatia & To promote quality eating to achieve quality living \\
\hline $\begin{array}{l}\text { Abergavenny- } \\
\text { Monmouthshire } \\
\text { County Council }\end{array}$ & Wales & $\begin{array}{l}\text { To make it a place where Culture, Cuisine and } \\
\text { Community is intrinsically linked, where local } \\
\text { produce is the purchase of choice for residents }\end{array}$ \\
\hline Mollet del Vallès & Spain & Eat well in Mollet \\
\hline Mouans- Sartoux & France & $\begin{array}{l}\text { To create a virtuous loop of circular economy in } \\
\text { agri-food systems and develop short and } \\
\text { sustainable food chains }\end{array}$ \\
\hline $\begin{array}{l}\text { Pays } \\
\text { Condruses }\end{array}$ & Belgium & $\begin{array}{l}\text { To implement the } 3 \mathrm{H} \text { strategy, Health of the soil, } \\
\text { Economic Health and People's Health }\end{array}$ \\
\hline Cesena & Italy & $\begin{array}{l}\text { Strengthening the District of agro-food excellence } \\
\text { in Cesena }\end{array}$ \\
\hline Södertälje & Sweden & A sustainable and resilient future \\
\hline Pyli & Greece & $\begin{array}{l}\text { The best place to start producing sustainable } \\
\text { agrifood }\end{array}$ \\
\hline
\end{tabular}

Source: authors.

\section{Cities on the move. The role of IAPs}

Since the beginning, IAPs were not conceived as administrative exercises but as strategic tools that combine short-term actions with long-term visions in response to the themes of the network. One of the key insights of the project has been the involvement of policy makers working together with practitioners, local inhabitants and entrepreneur in each partner city to develop IAPs. Each IAP is unique, in terms of local context, theme and coverage, but the cities have not operated in isolation, rather they inter-twinned forces and learnt from each other. Cities have continuously interacted, organizing joint activities, field visits, entrepreneurs and policymakers exchange experiences, transnational visits, etc.

Four different themes were set up at the beginning of the project. All of them were considered as essential parts of creating successful local food systems, and at the same time they are strongly interlinked; focusing on any of them will automatically enforce the other themes as well. These themes are: Ensuring short circuits; Smart land use; Business development of SMEs and Local public procurement.

The actions included in the IAPs aimed to develop inclusive, coherent and reflexive urban-rural food governance systems through municipal integrated action plans; to deploy a more solid social and physical infrastructure that reduce the distance between producers and consumers and promote circular economy; to create reliable markets for quality food producers and opportunities for SMEs development; to experiment new forms of entrepreneurship in the agricultural sector, and to create new jobs and skills linked to the agri-food system. Table 2 summarises the different actions included in each of these four themes. 
Table 2. Actions included in each partner city IAP.

\begin{tabular}{|c|c|}
\hline City & IAPs action \\
\hline \multicolumn{2}{|c|}{ ENSURING SHORT CIRCUITS } \\
\hline Cesena & $\begin{array}{l}\text { The AGRI-URBAN Markets for the sale of agri-food products (farmer } \\
\text { markets) } \\
\text { Mapping to Connect - create a network of producers, consumers and } \\
\text { universities }\end{array}$ \\
\hline Jelgava LM & $\begin{array}{l}\text { Development of a local products and services support system } \\
\text { Facilitation of the recognition of products and services from the } \\
\text { municipalities } \\
\text { Provision of support instruments for the development of local business } \\
\text { activities }\end{array}$ \\
\hline $\begin{array}{l}\text { Mollet del } \\
\text { Vallès }\end{array}$ & $\begin{array}{l}\text { Promote local, organic and seasonal menus in city restaurants } \\
\text { Increase the availability of local products in the municipal market } \\
\text { Set-up a stand at the weekly outdoor market in Mollet to sell local products } \\
\text { Build a Food Hub (logistics centre and warehouse) to distribute local } \\
\text { products } \\
\text { Create a route of "Eat Well in Mollet" eateries across the city } \\
\text { Create an online store in which orders are filled by the food hub }\end{array}$ \\
\hline Abergavenny & $\begin{array}{l}\text { Development of a Food Hub - To promote economic growth in the food } \\
\text { sector }\end{array}$ \\
\hline Petrinja & $\begin{array}{l}\text { Use a facility (the Green House) for promotion and marketing of the agri- } \\
\text { food products. }\end{array}$ \\
\hline Fundão & $\begin{array}{l}\text { Mapping of Supply and Demand - Know the local supply and its potential to } \\
\text { meet the needs of canteens (products, quantities, delivery regularities). } \\
\text { Sensitization and Training actions - } \\
\text { Fundão APP local products - Stimulate the activity of local producers } \\
\text { through institutions that provide school meals }\end{array}$ \\
\hline Baena & $\begin{array}{l}\text { Baena Food Hub } \\
\text { Social Orchards - food production and consumption for the benefit of } \\
\text { Baena's families. } \\
\text { "Social Harvest of Baena". Support for food production and consumption } \\
\text { by NGOs and associations of cultural and social interest } \\
\text { Promote the practice of production and consumption of local and } \\
\text { ecological foods accessible to all citizens } \\
\text { Editable city. Planting of trees, aromatic and edible plants }\end{array}$ \\
\hline Pyli & $\begin{array}{l}\text { Provoke the turn of the agri-food and forestry production to modern ways } \\
\text { of high value and quality but still traditional products. }\end{array}$ \\
\hline Mouans- & Link between local production and the municipal social grocery store \\
\hline Sartoux & $\begin{array}{l}\text { Food security and sustainable agriculture promoting access for everyone to } \\
\text { quality food and a nutritional balance } \\
\text { Supporting short food supply chains and direct marketing for farming } \\
\text { produce Support and involvement in fair trade (local and with southern } \\
\text { countries) }\end{array}$ \\
\hline $\begin{array}{l}\text { Pays de } \\
\text { Condruses }\end{array}$ & $\begin{array}{l}\text { Visibility and local consumption - Reinforce the visibility of the territory } \\
\text { actors that are developing activities to stimulate short circuit practices }\end{array}$ \\
\hline \multicolumn{2}{|c|}{ SMART LAND USE } \\
\hline $\begin{array}{l}\text { Mollet del } \\
\text { Vallès }\end{array}$ & $\begin{array}{l}\text { Develop a guide to manage school gardens in Mollet in collaboration with } \\
\text { primary school directors } \\
\text { Facilitate access to land to attract young agricultural producers interested } \\
\text { in organic agriculture }\end{array}$ \\
\hline Abergavenny & $\begin{array}{l}\text { Access to Land - This plan refers to "Old Lands" Community Supported } \\
\text { Agriculture (CSA) as one example of landowners wanting to use his land for } \\
\text { agro-ecological farming, veg boxes etc. }\end{array}$ \\
\hline
\end{tabular}




\begin{tabular}{|c|c|}
\hline Södertälje & $\begin{array}{l}\text { Municipal vegetable farm - To be able to serve meals in Södertälje's schools, } \\
\text { kindergartens and elderly care homes }\end{array}$ \\
\hline Baena & $\begin{array}{l}\text { Technical study, regulatory proposal and promotion campaign for the } \\
\text { creation of a Bank of local land. } \\
\text { School Gardens: Participation of schoolchildren in a school garden } \\
\text { experience either on their own educational center or in another suitable } \\
\text { space for this purpose }\end{array}$ \\
\hline $\begin{array}{l}\text { Mouans- } \\
\text { Sartoux }\end{array}$ & $\begin{array}{l}\text { Developing organic farming for sustainable water resource management } \\
\text { Preservation of natural and farming areas to increase territories' resilience. } \\
\text { Ecosystems conservation: Mouans-Sartoux is a o pesticide } 100 \% \text { organic city. }\end{array}$ \\
\hline Petrinja & $\begin{array}{l}\text { Establishing an agricultural zone in Petrinja's rural areas to stimulate the } \\
\text { agri-food production }\end{array}$ \\
\hline $\begin{array}{l}\text { Pays de } \\
\text { Condruses }\end{array}$ & $\begin{array}{l}\text { Agricultural production system based on a better use of ecological } \\
\text { functionalities in order to "produce more and better with fewer natural } \\
\text { resources". }\end{array}$ \\
\hline \multicolumn{2}{|c|}{ BUSINESS DEVELOPMENT OF SMES } \\
\hline Cesena & Start-up School - "new way" of doing business is feasible also in agriculture \\
\hline $\begin{array}{l}\text { Mollet del } \\
\text { Vallès }\end{array}$ & $\begin{array}{l}\text { Launch an agricultural incubator for young entrepreneurs } \\
\text { Develop the "Eat Well in Mollet" - as a symbol of nutritious, local, organic } \\
\text { and sustainable food. } \\
\text { Promote food tourism }\end{array}$ \\
\hline Abergavenny & $\begin{array}{l}\text { Education - to support advisory and training services on sustainable food } \\
\text { systems }\end{array}$ \\
\hline Petrinja & $\begin{array}{l}\text { Building the facilities for processing, production and packaging of meat and } \\
\text { vegetables (Cooperative Banovina) } \\
\text { \#Made_in_Petrinja as a project that will aim on branding, marketing and } \\
\text { promotion of the local agri-food products } \\
\text { Setting-up the Agri-Food sector database } \\
\text { Producers Club - will help the agri-food producers from rural areas to place } \\
\text { their products on the market and increase their sale. } \\
\text { One Stop Agricultural Shop - will be an agri-food info-point located in the } \\
\text { headquarters of Petrinja's development agency PETRA } \\
\text { Educational course for fruit growing and wine production }\end{array}$ \\
\hline Södertälje & $\begin{array}{l}\text { Farming Incubator - To lower the threshold for commercial farming in } \\
\text { Södertälje \& stimulate more locally grown produce } \\
\text { New-Old Knowledge - A range of courses open to the public which focus on } \\
\text { sustainable food production, homesteading and animal husbandry }\end{array}$ \\
\hline Baena & $\begin{array}{l}\text { Farming incubator to support young business to grow } \\
\text { Dynamization of the Baena Olive brand to promote agro-food culture. }\end{array}$ \\
\hline Pyli & $\begin{array}{l}\text { Biomass use for thermal production } \\
\text { Organize the producers to cooperative formations } \\
\text { Education-Knowledge on European laws, new products, new techniques } \\
\text { Promote eco-tourism as secondary activity by promoting eco local } \\
\text { products. }\end{array}$ \\
\hline $\begin{array}{l}\text { Mouans- } \\
\text { Sartoux }\end{array}$ & $\begin{array}{l}\text { Farming Incubator } \\
\text { Support to farmers - Create the good conditions for farmers' settlements. } \\
\text { Support farmers to develop sustainable business models. }\end{array}$ \\
\hline $\begin{array}{l}\text { Pays de } \\
\text { Condruses }\end{array}$ & $\begin{array}{l}\text { Sustainable Agribusiness Projects - Professionalization of our local } \\
\text { ecosystem to support sustainable agri-food projects. }\end{array}$ \\
\hline Jelgava LM & $\begin{array}{l}\text { Creation of a Smart Resource Board for the development of business } \\
\text { activity in the Jelgava municipality } \\
\text { Development of knowledge-based business activities }\end{array}$ \\
\hline
\end{tabular}




\begin{tabular}{|c|c|}
\hline \multicolumn{2}{|c|}{ PUBLIC PROCUREMENT } \\
\hline Mollet del & Implement a food model in the Mollet Health Foundation based on the "Eat \\
\hline Vallès & $\begin{array}{l}\text { Well in Mollet" values - promote healthy dietary habits amongst local } \\
\text { citizens }\end{array}$ \\
\hline & $\begin{array}{l}\text { Improve the quality of foods and beverages offered in public vending } \\
\text { machines }\end{array}$ \\
\hline & Define food indicators for the public canteens \\
\hline Fundão & $\begin{array}{l}\text { Pilot school - Meal preparation at the Silvares canteen with the introduction } \\
\text { of organic food (10\%) and local production ( } 80 \%) . \\
\text { Health \& organic food in schools }\end{array}$ \\
\hline Baena & Pilot plan in school dining rooms \\
\hline $\begin{array}{l}\text { Pays de } \\
\text { Condruses }\end{array}$ & $\begin{array}{l}\text { Organic and local school canteens - develop and improve the local Bio } \\
\text { school canteen project. }\end{array}$ \\
\hline Cesena & $\begin{array}{l}\text { "Organic Canteen Nearby" acts on the concept of sustainable school } \\
\text { canteen, enhancing the educational aspect and low environmental impact }\end{array}$ \\
\hline Moauns- & Social pricing of the school canteen meals according to families' income for \\
\hline Sartoux & $\begin{array}{l}\text { all the school going children, so that they have access to a } 100 \% \text { organic meal } \\
\text { every school day }\end{array}$ \\
\hline
\end{tabular}

Source: authors.

\section{AGRI-URBAN added value}

The project has delivered actions and reflections in several important topics: the need of sustainable diets, the role of European cities in Food Policy, the importance of reinventing local food systems and the need to reinforce the integrated connections between food and urban plans.

As can be appreciated in the list of actions described in Table 2, the project has embedded the concept of 'sustainable diets' (Gussow and Clancy, 1986; Mason and Lang, 2017) in the rationale of the local food systems. To be sustainable, diets need to be healthy for people, the planet and be accessible and affordable for all, providing fair returns, decent jobs and good working conditions with fully internalized costs. Sustainable diets must be culturally acceptable and of appropriate quality.

AGRI-URBAN towns have committed to develop local food strategies, public procurement for schools and hospitals sourcing healthy, sustainable food and using short supply chains wherever possible, and making the best use of land to produce a diversity of healthy, low environmental impact food.

The project has analysed the policy implications of sustainable food system. A recent study by the European Commission (Food in Cities 2017) aimed at promoting, from an innovative focus, the sustainability of food production and consumption in cities, has found a series of gaps in food plans taking place in European cities. Among these failures, it points out the lack of internal integration, the diffuse division of jurisdictional competences, the lack of multi-level governance, the absence of contact between research, policy and practical implementation or the difficulties of attracting critical actors within the food sector policy. In general, a direct relationship has been confirmed between these deficits and the multiple restrictions derived from the different areas of competence between levels of administration, as well as between the sectors or actors involved. Given this situation, the partner cities have responded with innovative alternatives based on approaches such as:

1. Strengthening the decision-making capacity that consumers and the local public administrations can exercise. 
2. Encouraging participatory governance systems.

3. Claiming the role of local politics.

4. Supporting the strengthening of short marketing channels.

5. Promoting the systemic approach. By making the food chain more visible, local governments find it easier to develop an approach that overcomes the classic division between production and consumption that characterizes food policies.

6. Trans-localism as a tool for cooperation between cities and territories, creating networks that allow the transfer of knowledge and that can also stimulate territorial approaches.

Table 2 gathered the main actions overtaken to rethink the local food systems. Several innovations linked to the development of network associative models by organic producers have contributed to creating a new dimension of quality food, as well as an important social and economic value from a renewed territorial and productive approach (Hochedez, 2013).

The incubation of small business and self-employment initiatives has been successfully tested by some of the partners, in particular in Condruses and Södertälje, while other cities just started to do so. Other actions are linked to the commitment to a circular economy model, focused on efficient and sustainable production while reducing waste around the food chain, and to offer an optimal space for the creation of new jobs along the entire food chain.

Additionally, AGRI-URBAN partner cities have committed to implement a global and integrated vision of the concept of 'sustainable food systems' as defined by Blay-Palmer (2015). This concept takes into account an integrated approach of the following elements: policy context (participatory democracy / multifunctionality, subsidiarity), environment (biodiversity and agro-biodiversity, soil and water, conservation, energy, food waste reduction ...), economy (land tenure, fair trade, market supply, food loss and waste, access to land, public procurement, migration and labour ...) and society (justice and equity, food access, food skills and literacy, traditional food knowledge, sustainable diets ...).

Other transversal elements considered key for the design of these territorial food systems are: i) a reinterpretation of the concept of Food Hub, understood as a useful organisational and socio-economic instrument interconnecting actors and technical / logistical solutions and designed from a scaling up perspective; ii) sustainable diets that consider the social and healthy dimensions for a holistic alternative; iii) breaking the borders - looking beyond urban boundaries and creating regional food systems and iv) smart use of technology and social innovations to promote food systems able to connect actors (governance) and to overcome barriers (market, natural boundaries, and jurisdictional boundaries, social and cultural exchange...).

As a final output of the project the partner cities have elaborated a Policy Declaration signed by all Mayors of the network: Local food policy and employment in small and medium sized European cities Manifesto (see Appendix).

\section{Final reflections}

AGRI-URBAN cities have developed actions and initiatives to nurture their specific visions. But their contributions have also nourished the conversation on the 
situation of local and territorial food systems, the challenges they face and the initiatives that can contribute to sustainably re-connect food and territories. The engagement and commitment of local policymakers in the project has guaranteed the political support to the action plans generated by each city.

The project outcomes reflect the vitality of the network of cities and the satisfactory cooperation generated between the actors. They have reached a high degree of shared knowledge and a good capitalization of it that has been expressed in the concrete content of the IAPs created.

These small cities are showing bigger cities the way forward. Their approaches take the urban and rural perspectives together - rather than seeing them as adversaries and their perspectives rise above the narrowly sectoral.

The actions proposed contribute to the sustainable development and the resilience of these territories but also to advance in the implementation of the EU Urban Agenda giving answer to themes such as jobs and skills, sustainable use of land, circular economy and urban poverty.

\section{Acknowledgments}

We would like to thank all the partners involved in the AGRI-URBAN Project for the successful work during this three-yearlong project and to their political representatives for their commitment to the project. Our gratitude also goes to the URBACT European exchange and learning programme for their invaluable support and technical and financial assistance throughout the project.

\section{REFERENCES}

BLAY-PALMER, A. Sustainable transformation through city-region food systems. 2015.

CARON, P. et al. Food systems for sustainable development: proposals for a profound four-part transformation. Agronomy for Sustainable Development, 38(4), 41. doi:10.1007/s13593-018-0519-1. 2018.

EUROPEAN COMMISSION. Food in cities: study on innovation for a sustainable and healthy production, delivery, and consumption of food in cities. 2017.

GUSSOW, J. D., and CLANCY, K. L. Dietary guidelines for sustainability. Journal of nutrition education, 18, 1-5, 1986. Disponível em:

http://www.fondazionecariplo.it/static/upload/bla/blay-palmer.pdf.

MASON, P. and LANG, T. Sustainable Diets. Earthscan. 2017.

UNEP. Food Systems and Natural Resources. Report of the Working Group on Food Systems of the International Resource Panel. Westhoek, H, Ingram J, Van Berkum, Ozay L and Hajer M. 2016. 
Maria Mar Delgado-Serrano. Profesora Titular Departamento Economía, Sociología y Política Agrarias da Universidad de Córdoba.mmdelgado@uco.es

Antonio Zafra. Asociación para el Desarrollo del Guadajoz.azafra@adegua.com

Miguel Sousa. INOVA- Portugal.miguel.sousa@inovamais.pt

\section{Submetido em: 19/03/2019}

Aprovado em: 10/12/2019

Como citar: DELGADO-SERRANO, Maria Mar; ZAFRA, Antonio; SOUSA, Miguel. As raízes da cidade. Sistemas alimentares criativos nas pequenas cidades europeias. Redes (St. Cruz Sul, Online), Santa Cruz do Sul, v. 25, n. 1, jan. 2020. ISSN 1982-6745. DOI: https://doi.org/10.17058/redes.v25i1.13327. 


\section{Appendix}

\section{LOCAL FOOD POLICY AND EMPLOYMENT IN SMALL AND MEDIUM SIZED EUROPEAN CITIES MANIFESTO of Mollet del Vallés (BARCELONA)}

WE, the Mayors and Representatives of the small and medium-sized European cities gathered in the AGRI-URBAN Network, under the URBACT III Program,

\section{Inspired by:}

> The important role that the European Union attaches to food policy, given its complex economic, social, cultural and, especially, food security dimensions

$>$ The different experiences and projects connected with the production and consumption of healthy, local spreading across the European Union, in response to a growing concern and commitment of citizens

The agreements and positions expressed at political level by numerous institutions and private sector representatives as well as civil society, noting in particular the importance of the Milan Urban Food Policy Pact

\section{Recognising that:}

$>$ Local and organic production is a very appropriate response to the present needs in order to ensure a sustainable future for our cities

$>$ Consumers and society as a whole demand healthy and sustainable food

$>$ The small and medium sized cities, with a significant functionality still linked to the agri-food production, organise the territory and link rural and urban areas

$>$ The agro-towns or cities with this special productive functionality have a high potential for job creation in this sector

$>$ The local identity and brand of these cities is positively reinforced thanks to this specialization that can connect tradition with innovation and technological advances

\section{Manifesting:}

Our decision to undertake, within the network of cities gathered in the AGRI-URBAN project, a process of critical reflection on foodstuff production in our typology of small and medium sized European cities, in order to incorporate this specialisation in the sustainable and integrated development models of our municipalities.

Defining some of the key issues in order to seize the opportunity that local food systems represent, among others:

$>$ Short circuits of production and consumption

$>$ Access to land

$>$ Promoting employment and entrepreneurship in the sector

$>$ Public procurement committed to local production models and quality, preferably organic 
We commit to:

Developing Integrated Local Action Plans aimed at promoting local food production and consumption in line with the ideas previously exposed

Streamlining all actors of civil society, businesses and institutions to promote their commitment to these policies and ensure their active participation in defining and monitoring them

Disseminating in our cities, countries and the whole European Union the results of our common work and the lessons learned, contributing in particular to strengthening the transnational work of agri-food small and medium sized cities

In Mollet del Vallès (Barcelona), June 9, 2016 